\title{
Suicide gene therapy: A promising approach towards gene delivery
}

\author{
Archna Panghal, Harish Sharma, SJS Flora and Saba Naqvi* \\ Department of Pharmacology \& Toxicology, National Institute of Pharmaceutical Education and Research, Raebareli, New Transit Campus, Bijnor Road, Sarojini \\ Nagar, Near CRPF Base Camp, Lucknow, India
}

\begin{abstract}
Nowadays, among various gene therapy methods for cancer, the use of suicide gene therapy is gaining the interest of researchers because it has shown great potential for the treatment of cancer in an efficient manner than conventional cancer chemotherapies. In this therapy, a gene, encoding for an enzyme of non-mammalian origin which possess ability to change a nontoxic, safe prodrug into metabolites which are toxic to cells, is delivered to the cancer cells. As a result, the activated prodrug demonstrate killing effect on the transfected cancer cells as well as non-transfected cells by exhibiting bystander effect either via gap junctions or by several other mechanisms. Despite noteworthy advancements that has been made in the field of suicide gene therapy, this approach has not delivered significant outcomes in clinical trials and even a single enzyme/prodrug system has not made its way to clinic due to several challenges. The main issues that are hampering the applicability of suicide gene therapy from bench to bedside include slow prodrug to drug conversion rate, inadequate transfection/transduction efficiency of the vectors, and nonspecific toxicity/immunogenicity issues due to the delivery systems, plasmid DNA, enzymes, and prodrugs. This review provides a comparative synopsis of the various vectors involved in gene therapy along with an overview of the suicide gene therapy with special emphasis on most widely used enzyme/prodrug systems.
\end{abstract}

\section{Introduction}

Gene therapy, a miracle which was unbelievable almost three decades ago, is a new emerging strategy for current research in biomedical, pharmaceutical and biotechnological field. Gene i.e., our fate determining factors, are the functional unit of heredity and any mutation in genetic sequencing is responsible for a large number of diseases. Gene therapy has shown tremendous potential for treating such disease. In simple terms, gene therapy is replacement of defective gene, responsible for disease, with a new healthy and functional gene. With the advent of gene therapy, new treatment approaches showing great effectivity than conventional treatment strategies for treatment of genetic disease including monogenic disease such as cystic fibrosis and other complex cardiovascular, nervous and autoimmune disorders have been searched out. Besides this, gene therapy approach can also be used as a mean for treatment of polygenic and acquired disease by stimulating immune response through delivered genes, delivering suicide genes responsible for cell death, targeting cells with genes modifying cellular information [1]. The ultimate goal of all these therapies is to achieve a stable expression of transgenes in target cells, in an appropriate regulated manner, demonstrating no side effects like alteration in pre-existing human genome, cellular toxicity except in suicide gene therapy. Gene therapy involves delivery of gene of interest in target cell either by viral vectors involving the use of adenoviruses, retroviruses, Herpes simplex virus (HSV) and many more, or by nonviral vectors such as mechanical and physical methods. Once delivery of genes inside body is accomplished, a sequence of events including uptake by endocytosis, release of DNA into cells, transcription followed by translation occur to express protein of interest [2].

Suicide gene therapy, also called as Gene-Directed Enzyme/ Prodrug Therapy (GDEPT), is considered as an alternative approach to treat tumor cells. In brief, this approach involves delivery of foreign genes which encode for the enzymes having ability for the conversion of non-toxic prodrug into toxic metabolites resulting into death of the host cells. Besides this, suicide genes also exhibit bystander effects on neighbouring cells by predisposing them to the effects of toxic metabolites. Among many suicide genes, E. Coli Cytosine Deaminase (CD) and Herpes Simplex Virus thymidine kinase (HSVtk) are well documented for their strong therapeutic efficacy in cancer treatment [3].

\section{Vectors involved in gene therapy}

Vectors are the viral and non-viral vehicles which are used to carry genes into the host cells. Though, naked DNA encoding the therapeutic

${ }^{\star}$ Correspondence to: Naqvi S, Department of Pharmacology \& Toxicology, National Institute of Pharmaceutical Education and Research, Raebareli, New Transit Campus, Bijnor Road, Sarojini Nagar, Near CRPF Base Camp, Lucknow (UP)- 226002, India, Tel: 0522-2497903; E-mail: writetosaba@yahoo.com and communication no. NIPER-R/Communication/064

Special Issue: Nanotechnology: Challenges and Perspectives in Medicine

Dr. Federica Valentini

Department of Sciences and Chemical Technologies

Tor Vergata University

Italy

Maurizio Talamo

Professor

Department of Enterprise Engineering

Italy

Key words: suicide gene therapy, bystander effect, vector, prodrug, enzyme, cancer

Received: February 19, 2019; Accepted: March 11, 2019; Published: March 29, 2019 
protein can directly be injected into host cells, but the low efficiency strengthens the need for special carriers. In gene therapy, properties of vectors such as enough targetability, transfection efficiency enough targetability, transfection efficiency and safety must be developed first in order to have extensive and successful use of gene therapy for mankind. An ideal vector for gene delivery should possess some of the following properties:

- Ability to deliver the load in specific cells; specificity/targetability

- Ability to resist metabolic degradation; stability

- Minimal side effects; safety

- Ability to express in regulated fashion; Expressbility

Two kinds of vectors have been exploited most widely as vehicles for gene delivery: Viral vectors like retrovirus and adenovirus etc. and non-viral vectors which are further subdivided into various categories like physical vectors, mechanical vectors and chemical vectors. Each vector has its own benefits and drawbacks and no vector fulfill all the criteria of an ideal vector till now [4].

\section{Viral vectors}

Viruses have an ability of transduction i.e. introducing their genetic material in host cell due to which they are widely employed as vectors for gene delivery. The most successful viral gene delivery vehicles available today are retroviruses, adenoviruses, adeno-associated viruses (parvoviruses), herpes viruses, pox viruses, lentiviruses, and others. These gene delivery systems are developed by slight modifications in their genetic material by introducing a foreign gene which encodes for required protein [5].

However, several other viruses are under investigation to date and recently, many more different virus vector systems are being developed. These are derived from vaccinia virus, Human cytomegalovirus (HCV), Epstein-barr virus (EBV), but their utilization in gene therapy is limited due to problems, such as their immunogenicity, cytotoxicity, insertional mutagenicity and carcinogenicity properties and inability for long term transgene expression [6-13].

\section{Nonviral vectors}

Nonviral methods of gene transfer are less efficient than viral systems in gene transduction, yet they are considered as an attractive tool for gene delivery due to their properties such as cost-effectiveness, availability, reduced immunogenicity, bio-safety, and ability to deliver required size of transgenic DNA and few others. Nonviral delivery system comprises of either physical methods such as electroporation, sonoporation, laser irradiation, micro-injection, and gene gun methods or chemical methods such as cationic liposomes, cationic polymers, lipid polymers etc. For instance, Parayath, et al. demonstrated the repolarization of tumor-associated macrophages in a genetically engineered nonsmall cell lung cancer model by intraperitoneal administration of hyaluronic acid-based nanoparticles encapsulating microRNA-125b [14]. Unfortunately, none of the currently available nonviral delivery systems fulfills ideal vector properties [12]. Figure 1 explains the results of the uptake of the HA-PEI-125b nanoparticles by peritoneal macrophages. These peritoneal macrophages then migrate to the lung tumor tissue depleted of macrophages, resulting in an increase in repolarization of tumor-associated macrophages.

The simplest technique of nonviral gene transfer is naked plasmid DNA which has been used in various pre-clinical and clinical trials. The successful implication of naked DNA was made in the field of therapeutic angiogenesis in myocardial ischemia for delivery of vascular endothelial growth factor (VEGF) gene [15] (Figure 2).

\section{Suicide gene therapy}

The basis of suicide gene therapy also known as Gene-directed enzyme/prodrug therapy (GDEPT) is delivery of foreign genes encoding for a non-mammalian enzyme which convert non-toxic prodrug into toxic metabolites selectively in tumor cells. It is a way of inducing anticancer activity at the tumor site on the ground of minimum impact on normal tissues via the combined use of passive, active, and transcriptional targeting strategies. This approach is advantageous over conventional cancer therapies such as chemotherapy and radiation therapy in two means [16-18].

The first advantage is targetability which is indicative of expression of genes selectively in tumor cells but not in normal cells and is achieved by putting the suicide gene under the control of a tumorspecific promoter [19]. Consequently, the prodrug is activated only in tumor environment reducing its off-target toxicity. Until 2000s, a wide range of cancer tissue specific promoters such as human telomerase reverse transcriptase (hTERT) promoter, carcino-embryonic antigen (CEA) promoter, osteocalcin (OC) promoter have been developed [20]. In the recent years, various new promising promoters like auxin response factors (ARF) [21], glucose-regulated protein (GRP78) [22], chemokine (C-X-C motif) receptor-4 (CXCR4) [23,24], osteopontin (OPN) [25], and many more have been developed which have attracted attention of researchers. Though, all these promoters have been found efficient, hTERT is the only that has made successful entry in clinical trials [26]. The major problem for clinical translation of transcription targeting is low transcriptional power of cancer-specific promoters due

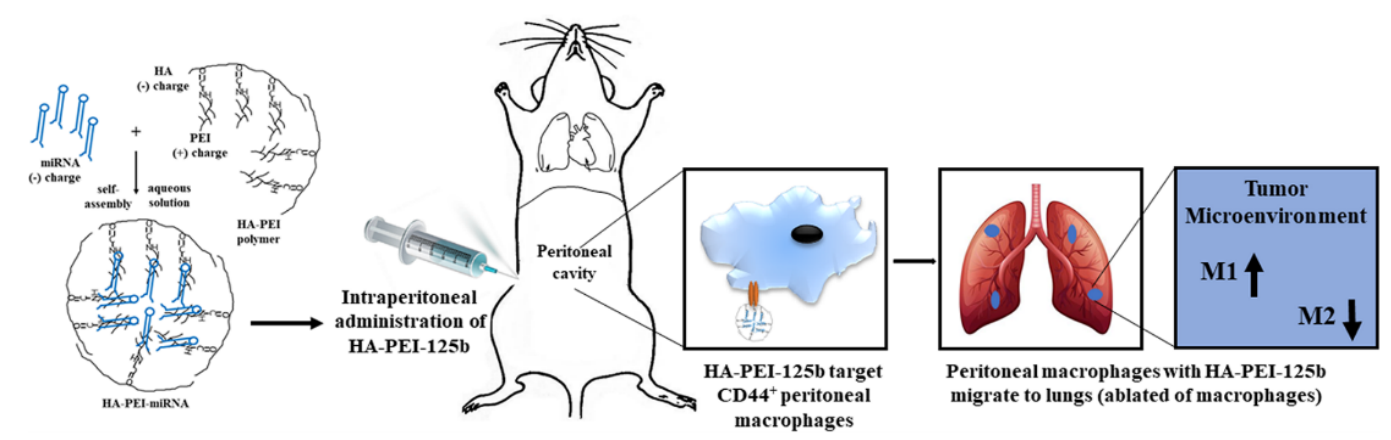

Figure 1. Schematic Representation of Intraperitoneal Administration of Hyaluronic Acid-Poly(ethylene Imine) (HA-PEI)-microRNA 125b (Reprint with permission from Parayath, N.N.; Parikh, A.; Amiji, M.M. Repolarization of tumor-associated macrophages in a genetically engineered nonsmall cell lung cancer model by intraperitoneal administration of hyaluronic acidbased nanoparticles encapsulating microRNA-125b. Nano Lett., 2018, 18, 3571-3579. Copyright @ 2018, American Chemical Society). 


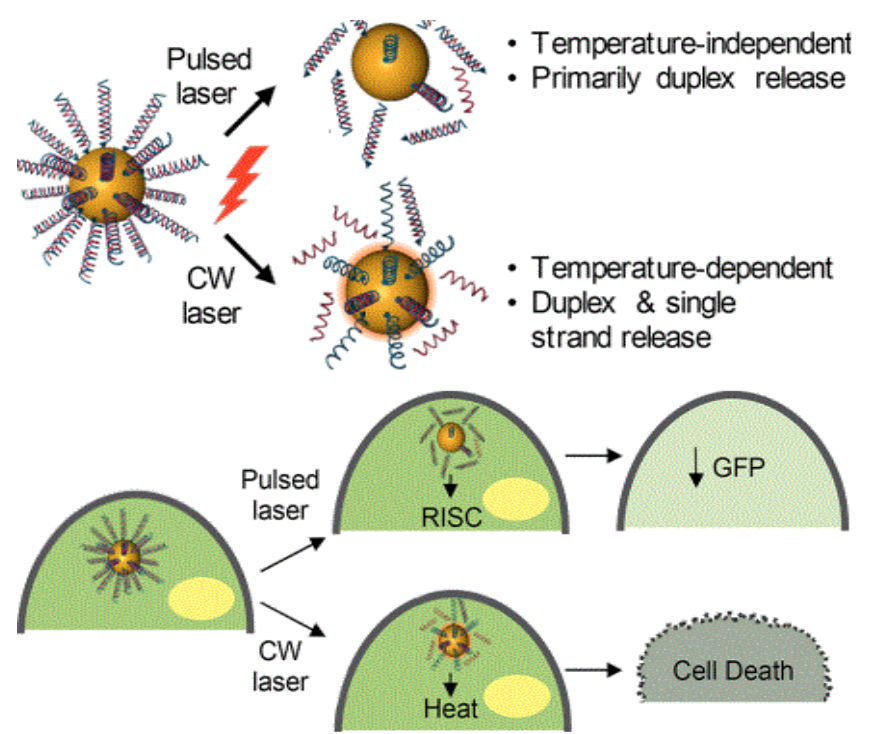

Figure 2. Gene Regulation with siRNA-NanoShell conjugates;RISC=RNA induced silencing complex; $\mathrm{CW}=$ Continuous wave. (Reproduced with permission from Riley, R.S.; Dang, M.N.; Billingsley, M.M.; Abraham, B.; Gundlach, L.; Day, E.S. Evalutaing the mechanisms of light-triggered siRNA release from nanoshells for temporal control over gene regulation. Nano Lett., 2018, 18(6),3565-3570. Copyright @ 2018, American Chemical Society)

to which low level of suicide gene expression is not enough to convert sufficient amount of prodrug to toxic molecules. To overcome these hurdles, chimeric and artificial promoters are under investigation [26-28].

The second advantage that makes suicide gene therapy more successful and promising approach to tackle cancer than conventional gene therapy is bystander effect. Bystander effect demonstrates the destruction of neighbouring cells of the transduced cell. This phenomenon suggests that transduction of even less than $10 \%$ cells is enough to destroy whole tumor cell population [29]. This effect is mediated by transfer of toxic metabolites from transduced cells to nontransduced cells either passively or actively. Gap junctions are thought to play key role in mediating these effects as they allow concentration gradient mediated diffusion of toxic metabolites from transduced cells to neighbouring cells. Bystander effect is not a hypothetical one but has been observed in several in vivo models. For instance, in a mouse model of tumor, prodrug 5 -fluorocytosine insertion along with cytosine deaminase resulted in significant regression in all tumors even when suicide gene was expressed in $2 \%$ of tumor mass [30]. Beside diffusion of toxic metabolites via gap junctions endocytosis of apoptotic bodies released from dying cells by neighbouring non-transduced cells is another mechanism for bystander effect [31] (Figure 3).

\section{Pillars of suicide gene therapy}

Suicide gene therapy is believed as a successful alternative of chemotherapy and radiation therapy for dealing with tumors. The success of suicide gene therapy relies mainly on three components i.e. enzyme, prodrug and delivery system (vector) which are considered as important pillars of suicide gene therapy. Choosing appropriate combination of the above components is crucial for the success of suicide gene therapy.

Enzymes are important in suicide gene therapy because they are required for conversion of nontoxic prodrug to toxic metabolites resulting in toxic effects on transduced cells and other neighbouring non-transduced cells through bystander effects. Enzymes having usage in GDEPT can be classified into two classes. The first class includes enzymes of human origin like cytochrome P450 (CYP 450). The enzymes of this class are less likely to provoke any immune response, but they can induce off-target toxicity. The second class contains enzymes of viral and bacterial origin such as cytosine deaminase $(C D$, bacterial and yeast), herpes simplex virus thymidine kinase (HSVTK, viral), nitroreductase (NTR, bacterial) and carboxypeptidase G2 (CPG2, bacterial), among which the first two have been used extensively in suicide gene therapy. Second group enzymes are more immunogenic than first group enzymes, but they induce non-significant off-target toxicity. The expression of the enzymes in transfected cells is under the regulation of tumor-specific promoters like hTERT, CEA, GRP, OC, ARF etc. which restrict the enzyme expression only in tumor cells $[20,32]$.

Another important pillar of suicide gene therapy is prodrug which is converted to toxic metabolites to exert potential harmful effects on cells. These prodrugs are required to fulfil several criteria. They must serve as efficient and selective substrates for the activating enzyme, and be metabolized to potent cytotoxins having ability to kill cells at all phases of the cell cycle. Since gene transduction efficiencies are usually low, both prodrugs as well as their activated toxic metabolites should possess good distributive properties, so that the effectiveness of the therapy can be maximized by enhancing bystander effect. Lipophilicity of the activated form is a vital parameter to determine the bystander effects produced by passive diffusion. The bystander effect of many of the early antimetabolite-based prodrugs was just dependent on diffusion via gap junctions because of limited ability of their polar activated forms to diffuse across cell. Afterward, various studies have demonstrated that more lipophilic and neutral compounds show better diffusion-based bystander effects. DNA alkylating agent based prodrugs, having less cell cycle-specificity than antimetabolites and more effectivity against noncycling tumor cells, appear to be more active prodrugs, requiring less prolonged dosing schedules to be effective [33,34].

Another most important component of GDEPT is delivery system (vectors) that carries desired genes to the target cells. The development of efficient gene delivery system to obtain optimized gene expression is the most challenging process in GDEPT. A wide range of viral and non-viral delivery systems as described in Tables 1 and 2 have been used in gene therapy $[1,16,17]$.

\section{Enzyme/prodrug systems}

Many enzyme/prodrug systems have been explored in the past years (Table 3) among which the most extensively studied pairs are herpes simplex virus thymidine kinase (HSV-TK) with ganciclovir (GCV), cytosine deaminase (CD) of Escherichia coli with 5-fluorocytosine (5FC), cytochrome P450 with cyclophosphamide/ifosfamide (CPA/IFA), and nitroreductase with $\mathrm{CB} 1954$. In the subsequent sections, we will focus on widely used enzyme/prodrug systems highlighting their most important characteristics.

\section{Thymidine kinase/Ganciclovir system}

Herpes simplex virus thymidine kinase (HSV-TK) enzyme along with the prodrug ganciclovir (GCV) is the most widely studied enzyme/ prodrug system. HSV-TK enzyme causes catalytic phosphorylation of GCV to GCV monophosphate which is subsequently converted to di- and triphosphate derivatives by endogenous kinases. The resulting metabolites are toxic as they cause DNA chain termination and apoptosis after incorporation in DNA by DNA polymerases [35]. This 


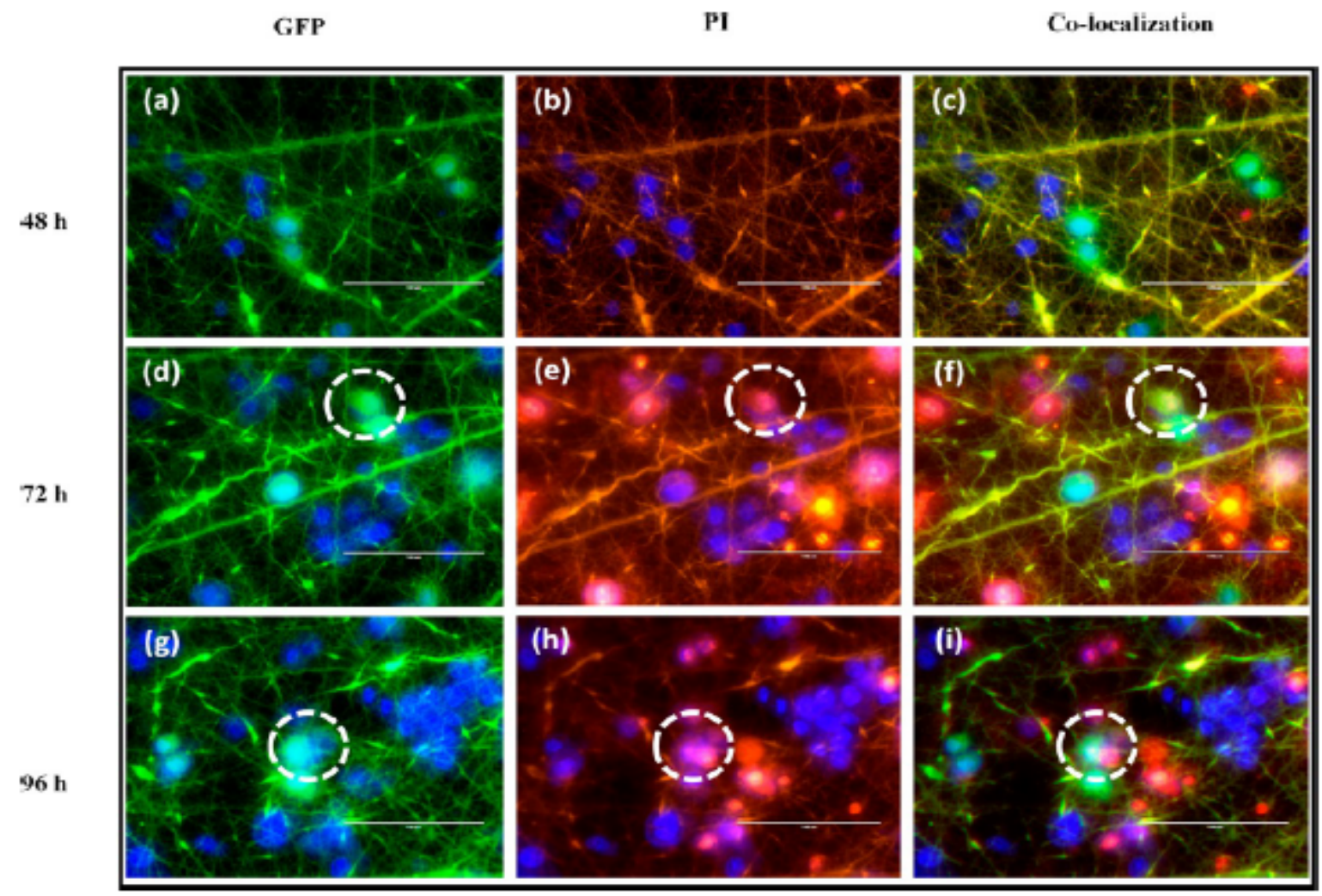

Figure 3. Bystander effects monitored by GFP expressing transfected or nontransfected cells at 48, 72, and 96 h, respectively, and (b, e, h) PI stained dead or live cell. (c, f, i) Reprint with permission from Sukumar, U.K.; Packirisamy, G. Bioactive core-shell nanofiber hybrid scaffold for efficient suicide gene transfection and subsequent time resolved delivery of prodrug for anticancer therapy. (ACS Appl. Mater. \& Interfaces, 2015, 7(33), 18717-18731. Copyright @ 2015, American Chemical Society).

Table 1. A brief summary of viral vectors

\begin{tabular}{|c|c|c|c|c|c|}
\hline & Adenovirus & Adeno-associated virus & Alphavirus & Herpes virus & Retrovirus/Lentivirus \\
\hline Examples & Human adenoviral serotypes & $\begin{array}{l}\text { Human parvovirus, } \\
\text { AAV-1, AAV-6 }\end{array}$ & $\begin{array}{l}\text { Sindbis virus, } \\
\text { Semliki forest virus }\end{array}$ & $\begin{array}{l}\text { HSV-1 } \\
\text { HSV-2 }\end{array}$ & $\begin{array}{l}\text { Vesicular stomatitis virus, } \\
\text { Human foamy Virus }\end{array}$ \\
\hline Genome & DsDNA & ssDNA & ssRNA & dsDNA & ssRNA \\
\hline Host genome interaction & $\begin{array}{l}\text { Non-integrating with host } \\
\text { chromatin }\end{array}$ & $\begin{array}{l}\text { Non-integrating with host } \\
\text { Chromatin }\end{array}$ & $\begin{array}{l}\text { Non-integrating with host } \\
\text { chromatin }\end{array}$ & $\begin{array}{l}\text { Non-integrating with host } \\
\text { chromatin }\end{array}$ & $\begin{array}{l}\text { Integrating with host } \\
\text { chromatin }\end{array}$ \\
\hline Transgene Expression & Transient & Potential long lasting & Transient & Potential long Lasting & Long lasting \\
\hline Packaging Capacity & $7.5 \mathrm{~Kb}$ & $4.5 \mathrm{~Kb}$ & $7.5 \mathrm{~Kb}$ & $>30 \mathrm{~Kb}$ & $8 \mathrm{~Kb}$ \\
\hline Immunogenicity & High & Low & High & High & Low \\
\hline Advantages & $\begin{array}{l}\text { Highly efficient transfection } \\
\text { in vivo and ex vivo, transfects } \\
\text { proliferating and non } \\
\text { proliferating host cells. }\end{array}$ & $\begin{array}{l}\text { Long duration of expression } \\
\text { especially in vivo, low } \\
\text { immune response in host }\end{array}$ & $\begin{array}{l}\text { Replication-competent, } \\
\text { broad host range, promising } \\
\text { approach for vaccine } \\
\text { production and tumor } \\
\text { management }\end{array}$ & $\begin{array}{l}\text { High packaging capacity, } \\
\text { effectivity for wide range } \\
\text { of host cell,good length of } \\
\text { expression }\end{array}$ & $\begin{array}{l}\text { Long-term } \\
\text { expression,effective } \\
\text { integration into target cell } \\
\text { chromatin }\end{array}$ \\
\hline Disadvantages & Immunogenic & Small Packaging Capacity & Host-cell toxicity & $\begin{array}{l}\text { Induces toxicity and } \\
\text { inflammation }\end{array}$ & $\begin{array}{l}\text { Integration may cause } \\
\text { oncogenesis }\end{array}$ \\
\hline References & {$[6,7]$} & {$[8,9]$} & {$[10,11]$} & {$[11,12]$} & {$[11,13]$} \\
\hline
\end{tabular}

system has been subjected to various preclinical studies leading to its application in several clinical trials for cancers like glioblastoma and prostate cancer.

The limitations of the HSV-TK/GCV system include severe immunogenic reactions due to the viral enzyme and ability to induce cell death only on actively dividing cells [36]. The second limitation is that GCV triphosphate exerts bystander effect via gap junctions due to which they exert limited therapeutic effects. In a recent study, it was demonstrated that the therapeutic activity GCV-triphosphate can be increased by enhancing the expression of connexin 32 (Cx32), the key component of gap junctions [37]. Furthermore, HSV-TK shows high affinity toward its natural substrate thymidine, which demands the need for using a high dose of GCV. The high dose itself can cause suppression of immune system and bone-marrow damage [38].

TK/GCV system has also been employed along with other therapeutic approaches to facilitate its anticancer efficiency. For instance, the combination of TK/valacyclovir with surgery and accelerated radiation increased patient survival rates in malignant glioma patients [39]. This combination has been found to be dual beneficial as on one side it increased the efficacy of the treatment, while on another side this has also decreased the toxicity in pancreatic adenocarcinoma. Currently, HSV-TK system is under couples of clinical 
Table 2. A brief summary of nonviral gene delivery systems.

\begin{tabular}{|c|c|c|c|c|}
\hline Delivery systems & Mechanism/Principle & Material & Advantages & Disadvantages \\
\hline \multicolumn{5}{|l|}{ In-vivo methods } \\
\hline Naked DNA / Plasmid DNA & Endocytosis & & Safety, Simplicity & Low transfection efficiency \\
\hline \multicolumn{5}{|l|}{ In-vitro methods: Physical } \\
\hline Microinjection & Manual injection (nuclear injection) & Micropipette, micromanipul-Ator & Very high efficiency & In vivo fastidious \\
\hline Gene gun & $\begin{array}{l}\text { High-velocity particle bombardment, } \\
\text { high pressure helium stream }\end{array}$ & Gene gun, gold beads & $\begin{array}{l}\text { Flexibility, Low cytotoxicity, Good } \\
\text { efficiency }\end{array}$ & Shallow Penetration \\
\hline Electroporation & $\begin{array}{l}\text { Enhancement of cell membrane } \\
\text { permeability/Electrophoretic } \\
\text { mobility }\end{array}$ & Electrodes, pulse generator & Good efficiency, Repeatable & $\begin{array}{l}\text { Tissue damage due to invasiveness } \\
\text { (electrodes) Accessibility of } \\
\text { electrodes to internal organs is limited }\end{array}$ \\
\hline Sonoporation & $\begin{array}{l}\text { Enhancement of cell membrane } \\
\text { permeability }\end{array}$ & Ultrasound probe, gas microbubbles & $\begin{array}{l}\text { Imaging during treatment, } \\
\text { Flexibility }\end{array}$ & $\begin{array}{l}\text { Low efficiency, toxicity to be } \\
\text { established }\end{array}$ \\
\hline Laser irradiation & $\begin{array}{l}\text { Enhancement of cell membrane } \\
\text { permeability due to laser beams }\end{array}$ & High-power laser source & $\begin{array}{l}\text { High efficiency precision of laser } \\
\text { beam }\end{array}$ & Toxicity potential \\
\hline Magnetofection & Pinocytosis and endocytosis & $\begin{array}{l}\text { Magnetic nanoparticles, magnetic } \\
\text { field }\end{array}$ & $\begin{array}{l}\text { Flexibility, Low Cytotoxicity, } \\
\text { Economic }\end{array}$ & Transient Transfection \\
\hline \multicolumn{5}{|l|}{ Chemical } \\
\hline Inorganic Molecules & Endocytosis & Calcium phosphate, silica, gold & Easy production & Low efficiency \\
\hline $\begin{array}{l}\text { Cationic lipids/Cationic liposomes } \\
\text { (Lipoplexes) }\end{array}$ & Endocytosis, DNA condensation & $\begin{array}{l}\text { Transfection reagents like } \\
\text { Lipofectin, Transfectam etc. }\end{array}$ & Easy production, Specific & $\begin{array}{l}\text { Low to medium efficiency, } \\
\text { Immunogenicity, Toxicity, less } \\
\text { Stability }\end{array}$ \\
\hline Polycations/Polyplexes & $\begin{array}{l}\text { Endocytosis, DNA condensation, } \\
\text { protein sponge effect }\end{array}$ & $\begin{array}{l}\text { Transfection polymers like Po PEI, } \\
\text { poly-L-lysine, p(DMAEMA) etc. }\end{array}$ & Low immune-genicity, & $\begin{array}{l}\text { Complement activation, Low } \\
\text { efficiency, Cytotoxicity }\end{array}$ \\
\hline Dendrimers & $\begin{array}{l}\text { Endocytosis, DNA condensation, } \\
\text { protein sponge effect }\end{array}$ & PAMAM dendrimers & Safety, low immuno-Genicity & $\begin{array}{l}\text { Cytotoxicity, low transfection } \\
\text { Efficiency }\end{array}$ \\
\hline Synthetic Peptides & $\begin{array}{l}\text { Multiple mechanisms, passive } \\
\text { passage, Endocytosis, recognition } \\
\text { by peptides }\end{array}$ & $\begin{array}{l}\text { Cell penetrating peptides like Tat } \\
\text { peptide, RGD peptide individually or } \\
\text { in combination with cationic lipids }\end{array}$ & $\begin{array}{l}\text { High Efficiency along with cationic } \\
\text { lipids }\end{array}$ & Mechanism not defined clearly \\
\hline
\end{tabular}

*PEI- Polyethyleneimine; p(DMAEMA)- Poly(2-dimethylamino)ethyl methacrylate; PAMAM poly(amidoamine); RGD: rginyl-glycyl-aspartic acid.

Table 3. A brief review of various enzyme/prodrug systems.

\begin{tabular}{|c|c|c|c|c|c|}
\hline \multirow{2}{*}{ Enzyme } & \multirow{2}{*}{ Prodrug } & \multirow{2}{*}{ Active metabolite } & \multirow{2}{*}{\begin{tabular}{|l|} 
Mechanism of \\
Action
\end{tabular}} & \multirow{2}{*}{\begin{tabular}{|l|} 
Bystander \\
Effect
\end{tabular}} & \multirow{2}{*}{ Reference } \\
\hline & & & & & \\
\hline $\begin{array}{l}\text { Herpes simplex virus } \\
\text { thymidine kinase }\end{array}$ & Ganciclovir (GCV) & $\begin{array}{l}\text { Ganciclovir Triphosphate } \\
\text { (GCV-TP) }\end{array}$ & $\begin{array}{l}\text { Blocks DNA synthesis. } \\
\text { S and G2 Phase arrest. } \\
\text { Mitochondrial damage. } \\
\text { Active in dividing cells. }\end{array}$ & Dependent of gap junctions & {$[40,41]$} \\
\hline Cytosine deaminase & 5-fluorocytosine (5-FC) & 5-Fluorouracil (5-FU) & $\begin{array}{l}\text { Blocks DNA and RNA } \\
\text { synthesis. Active mostly in } \\
\text { proliferating cells, but at high } \\
\text { concentrations can inhibit } \\
\text { growth of both proliferating } \\
\text { and non-proliferating cells. }\end{array}$ & High, independent junctions & {$[41,42,44]$} \\
\hline Nitroreductase & CB1954 and Analogs & $\begin{array}{l}\text { 2-Hydroxylamine and } \\
\text { 4-Hydroxylamine Derivatives }\end{array}$ & $\begin{array}{l}\text { Cross linking of DNA } \\
\text { interstrand. Active in both } \\
\text { proliferating and non- } \\
\text { proliferating cells }\end{array}$ & $\begin{array}{l}\text { Very High, Independent of } \\
\text { gap Junctions }\end{array}$ & {$[48,49]$} \\
\hline Carboxypeptidase G2 & CMDA, ZD-2767P & $\begin{array}{l}\text { N-4-[(2-Chloroethyl) } \\
\text { (2-mesyloxyethyl)amino] } \\
\text { benzoic acid (CMBA); Bis- } \\
\text { iodophenol mustard }\end{array}$ & $\begin{array}{l}\text { Cross linking of DNA } \\
\text { interstrand. Active in both } \\
\text { proliferating andnon- } \\
\text { proliferating cells. }\end{array}$ & $\begin{array}{l}\text { High, independent of gap } \\
\text { junctions }\end{array}$ & {$[55,56]$} \\
\hline Cytochrome P450 & $\begin{array}{l}\text { Cyclophosphamide, } \\
\text { Ifosfamide }\end{array}$ & $\begin{array}{l}\text { Phosphoramide mustard; } \\
\text { acrolein }\end{array}$ & $\begin{array}{l}\text { Cross linking of DNA } \\
\text { interstrand. Active mostly in } \\
\text { proliferating cells. }\end{array}$ & $\begin{array}{l}\text { Medium, Independent of gap } \\
\text { Junctions }\end{array}$ & {$[57,58]$} \\
\hline $\begin{array}{l}\text { Purine nucleoside } \\
\text { phosphorylase }\end{array}$ & 6-methylpurine deoxyriboside & 6-Methylpurine & $\begin{array}{l}\text { Inhibits DNA, RNA and } \\
\text { protein synthesis. Active in } \\
\text { both proliferating and non- } \\
\text { proliferating cells. }\end{array}$ & $\begin{array}{l}\text { High, independent of gap } \\
\text { junctions }\end{array}$ & {$[59,60]$} \\
\hline
\end{tabular}

trials for patients with high-risk acute leukemia (NCT00914628) and in patients with recurring prostate cancer (NCT01913106) (http://www. clinicaltrials.gov/).

\section{Cytosine Deaminase (CD)/ 5-fluorocytosine system}

The anticancer drug, 5-fluorouracil (5-FU) has been broadly used drug for dealing with a variety of cancers comprising colorectal, breast, head and neck solid tumors. It has been demonstrated to show better therapeutic effect when its prodrug form (5-fluorocytosine) is used in combination with bacterial enzyme cytosine deaminase (CD) in suicide gene therapy. The basic principle of this system is similar to other systems that is conversion of nontoxic prodrug (5-FC) to the active toxic metabolite (5-FU) by enzymatic (CD) activity [39]. After conversion to 5-FU, it diffuses readily to neighbouring cells due to being small in size and having neutral charge. 5-FU is then further converted to various metabolites by endogenous enzymes leading to formation of 
5FU-RNA and 5FU-DNA complex, inhibition of thymidylate synthase and finally apoptosis [40].

$\mathrm{CD} / 5$-FC system has various advantages over HSV-TK/GCV system including significant distant bystander effect independent of gap junctions. 5-FC, but not 5-FU, get access to brain by diffusion across blood brain barrier, therefore, several studies have given attention to the treatment of hard-to reach tumors such as glioblastoma [41]. Another advantage of $\mathrm{CD} / 5-\mathrm{FC}$ system is radiosensitizing ability of 5-FU due to which it can show enhanced tumor killing efficiency alonwith radiotherapy [42].

Although CD/5-FC system has several advantages, there are some disadvantages which overshadow the advantages of this system. The first limitation is the conversion of 5-FC to 5-FU by the normal gut microbes resulting in side effects. The other limitation is high affinity of bacterial CD (bCD) for cytosine, its natural substrate, which obliges the use of higher dose of 5-FC.

Many scientists have worked to form bCD mutants in order to advance its kinetics like high affinity and lower IC50 for 5-FC $[43,44]$. Kaliberova et al. found the sequence of a mutant, bCD-D314A, which demonstrated a remarkable specificity toward 5-FC with a lower IC50 as compared to Bcd [45]. Yeast CD (yCD) is another form of CD enzyme which exhibits few advantages over bCD including high affinity and improved ability for prodrug conversion. Furthermore, it has been seen that yCD in fusion with E.coli uracil phosphoribosyl transferase (UPRT), an enzyme absent in mammalian cells has significantly improved activity and enhanced cancer cell killing efficiency in prostate, ovarian, colon and breast cancers due to ability of UPRT to directly convert 5-FU to 5-FdUMP [46].

In clinical trials, $\mathrm{CD} / 5$-FC system has shown limited success, there are various clinical trials in progress which may demonstrate appealing results. For example, genetically modified stem cells expressing bCD along with orally administered 5-FC for the treatment of gliomas is under trial (NCT01172964). In another phase I - II study, an investigational drug APS001F is under examination along with a recombinant bacterium (Bifidobacteium longum) which can produce CD (NCT01562626). Moreover, the treatment of grade III/IV gliomas by using retroviral vector (Toca 511) in combination with 5 -FC is under phase I study (NCT01470794). (www.clinicaltrials.gov).

\section{Nitroreductase/CB1954 system}

This system consists of group of nitroreductase (NTR) enzymes that illustrates potency to activate prodrugs, such as CB1954 (5-(aziridin-1-yl)-2, 4-dinitro-benzamide). In this system, the explored enzymes have been classified in two classes while prodrugs have been put in four classes. The classification of enzymes in two categories has been depending on their sensitivity to oxygen. Type I NTR produces nitroso, hydroxylamine, and/or amine terminated products in the presence of molecular oxygen, in contrast, type II NTR produces these products in absence of oxygen [47]. The four classes of prodrugs comprises of dinitroaziridinyl benzamides, dinitrobenzamide mustards, 4-nitrobenzyl carbamates, and nitroindolines among which CB1954 belonging to dinitrobenzamide group is most widely used prodrug [48]. CB1954 is a DNA alkaylating agent which is converted to toxic metabolites by E.coli NfsB nitroreductase [49]. Once reduced by cellular thioesterase, CB1954 produces toxic metabolites which have ability of freely diffusing to surrounding cells and exhibit DNA chelating property, trigger extensive DNA damage and activate p53 and cell cycle independent apoptotic pathway in both dividing and non-dividing cells [50].
The important advantage of this system includes its ability to target non dividing cells in addition to dividing cells [50,51]. Another advantage is that side effects are restricted just to the modified cells and the cells in vicinity because of the intracellular activation of prodrug due to need of NADPH or NADH as an electron donor by NTR enzyme.

Despite promising results obtained by several studies, the low activation rate of CB1954, as it is not the natural substrate of NTR, is the major drawback of this system. Two general approaches including engineering and application of alternative CB1954-activating NTRs such as AzoR, NFsA, Nem A and synthesis of other NTR prodrug such as nitro-CBI-DEI and PR-104A have been adopted with the purpose of improving the efficacy of this system [51,52]. Both of these approaches have been found helpful to achieve appealing results in vitro as well as in vivo.

So far, a few clinical trials have been carried out with this system. In few clinical trials, this enzyme/prodrug system has been found to be effective for the management of prostate as well as liver cancers [53]. A phase I/II clinical trial was conducted in 2009 using replication-defective adenoviruses encoding NTR in which systemic administration of prodrug CB1954 was found to be efficacious for treatment of patients with localized prostate cancer [54]. In a phase I clinical study carried out in 2012 at UK, the efficacy of NTR/CB1954 system was tested in adenoviral vector along with a tumor specific promoter (human telomerase). This clinical trial (UK-0125) is still in progress and patients of intra-abdominal cancer were injected with this system subsequently the prodrug CB1954 was systemically administered [54].(www.clinicaltrials.gov).

\section{Carboxypeptidase G2/nitrogen mustard system}

The enzyme carboxypeptidase G2 (CPG2) is obtained from the Pseudomonas strain RS-16 and has no mammalian equivalents. This enzyme cleaves glutamic acid from nitrogen mustard (NM) based drugs to release the metabolites which unlike the products of other enzyme/prodrug system are active by itself without requirement of further modifications. The resulting alkylating metabolite is lipophillic and exhibit bystander effect by freely diffusing across cells without need of gap junctions and finally makes inter- and intra- strand DNA linkage. This enzyme/prodrug system has effect on both proliferating as well as non-proliferating cells and exerts bystander effect in both in vitro and in vivo systems $[55,56]$. Several nitrogen mustard compounds have been developed in recent few years among which CMDA (4-[(2-chloroethyl)(2-mesyloxyethyl)amino]benzoyl-L-glutamic acid) is the first developed prodrug which can be hydrolysed to glutamic acid and DNA alkylating agent 4-[(2-chloroethyl)(2-mesyloxyethyl) amino]benzoic [57-61]. It was reported that treatment of breast tumor expressing CPG2 with prodrug CMDA resulted in apoptosis in tumor cells, although the percentage of transduced cells was low [57]. Various efforts have been made to enhance the potency of CMDA. Development of ZD2767P, a nitrogen mustard derivative, having 300 times more potency than CMDA is one such attempt [62]. In order to enhance the enzyme efficiency, a mutated form of CPG2 was fused with vascular endothelial growth factor (VEGF) which resulted in binding of secreted CPG2 to VEGF receptor keeping CMDA around tumor mass and reduced systemic side effects [63]. This enzyme/prodrug system has been used in different clinical studies in combination with tumor-specific antibodies. However, issues like immunogenic reactions against mouse antibodies and CPG2 and insufficient localization of enzyme/antibody conjugate have restricted its successful application in cancer therapy. 
This system has been found to be highly applicable in clinical studies along with antibodies in antibody-directed enzyme prodrug therapy, in which, an enzyme is attached to a tumor-specific antibody either chemically or by protein fusion technology. The major reported toxicity of this approach was found to be myelosuppression due to long half-life of the drug and its escape to the systemic circulation [64].

\section{Cytochrome P450/oxazaphosphorine system}

Cytochrome P450 (CYP450) is an important class of enzymes that has an important role in metabolism of xenobiotics and is required for conversion of toxic drugs into non-toxic metabolites in the liver. These enzymes have a vital role in activation of oxazaphosphorine agents, anticancer drugs including cyclophosphamide (CPA) and ifosfamide (IFA) which act as substrates of CYP450 enzymes [65]. CYP450 enzymes metabolize these compounds to give 4-hydroxyderivative which react further to give phosphoramide and ifosphoramide mustard and acrolein which are responsible for DNA cross-linking and killing of cells. The resultant active metabolites exhibit potent bystander effect by transportation to the nearby cells independent of gap junctions [66]. As compared to other enzyme/prodrug systems, the main advantage of this system is less immunogenic reactions due to existence of P450 enzymes in human body [67].

The main disadvantage of this system is that the prodrugs are naturally metabolised by the hepatic P450 enzymes generating active toxic metabolites throughout the body that finally leads to diverse side effects like cardiotoxicity, bone marrow suppression, neurotoxicity and nephrotoxicity. Some of these toxicities have been found to be linked with the chloroacetaldehyde formation from CPA and IFA via $\mathrm{N}$-dechloroethylation [68]. The side effects related to this approach can be reduced by selective activation of prodrug in tumor sites, though a challenging task to achieve, but can be possible to achieve this goal by inhibiting P450 enzyme activity in the liver.

Several modalities have been tried to enhance the cancer treatment efficiency and lessen the side effects of P450 enzyme/prodrug system. In one such approach, CYP450/oxazaphosphorine treatment was given along with anti-thyroid drugs, such as propylthiouracil and methimazole in order to reduce hepatic P450 reductase activity and increase the selective activation of prodrug in tumor cells [69]. In phase I/II trial carried out in 2003, the efficiency of this system was tested in fourteen patients with pancreatic tumor who were treated with genetically modified allogenic cells to express CYP2B1. The cells were delivered to the tumors via tumor vasculature and then low dose IFO was administered after two days of cell injection [70]. In a different phase I/II clinical trial carried out in 2005, CYP2B6 gene was delivered in total of nine patients with breast cancer and three with melanoma by using human CYP2B6 commercial retroviral vector, MetXia [71]. Currently, several scientists are involved in developing new mutants of CYP2B6 with the aim of improving the affinity towards CPA. For instance, in one study, the structure of a triple mutant CYP2B6 was fused with NADPH, and conversion rate from CPA to its cytotoxic form was found to be enhanced [72].

\section{Purine nucleoside phosphorylase/6-methylpurine deoxyriboside system}

Purine nucleoside phosphorylase (PNP) is a hexameric enzyme obtained from E.coli. This enzyme act as a catalyst in glycosidic cleavage of purine ribonucleoside prodrugs like 6-methylpurine2deoxyriboside and fludarabine to give 2-deoxyribose-1-phosphate (or arabinose-1-phosphate) and free base compounds like 6-methylpurine and 2-fluoroadenine respectively. These both compounds exhibit ability to diffuse freely across cell membranes and demonstrate potent bystander effect on both dividing as well as non-dividing cells [73]. The cell-cell contact or gap junctions are not pre-requisite to demonstrate bystander effect and nucleotide and/or nucleobase transporters facilitate bystander effect across membranes in both directions. The active prodrug exhibits bystander effect on both proliferating as well as non-proliferating cancer cells because of its mechanism of action which is free of DNA synthesis [74]. The active metabolites block the protein synthesis after incorporation in genetic material during RNA synthesis. Immunogenicity from the bacterial PNP is the main limitation of this system which led researchers to develop human PNP (hPNP) mutants which possess ability to cleave adenosine based prodrugs which were not recognised by wild-type hPNP [74]. These mutants are attracting the attention of the researchers because of their ability in cleaving (deoxy) adenosine-based prodrugs and producing high amount of cytotoxic metabolites in preclinical studies [75,76].

So far, just one phase I clinical trial (NCT01310179), started in 2011 by PNP Therapeutics, has been conducted with this system. This trial was carried out in patients of head and neck cancers or other solid tumors in order to investigate the safety of E.coli PNP/fludarabine phosphate and no data has been released yet (www.clinicaltrials.gov).

\section{Conclusions}

Suicide gene therapy has shown promising outcomes against cancer while reducing toxic effects of chemotherapy drugs on normal tissues. It is gaining the interest of scientists and significant progress has been made in this field since its introduction in 1984. Several suicide gene therapy systems have been investigated including HSVTK / GCV, CD/5-FU and many more. Moreover, a number of vectors including various viral, non-viral and cellular vectors have been adopted. These vectors permit the delivery of suicide genes specifically to the cancer location and bystander effect is exerted beyond the target cells to surrounding cells either via gap junctions or by several other mechanisms. Being promising, this approach is progressing slowly since merely 45 clinical trials have get into phase III, one in phase IV and none entered to clinical use. One of the key specific causes to this slow progress has been the low transduction rate of the vectors, particularly in firm and dense tumors where the cells at the inner layers of tumor are hard to get into reach. In order to achieve bench to bedside translation of this approach, the issues like lack of a suitable delivery technique, short-term and low expression of transgenes, low prodrug's conversion rate and narrow bystander effect, need to be dealt with. Therefore, the demand of the hour is to divert the research toward enzyme engineering and prodrug development in order to speed up the development of stable/high affinity enzymes along with safe prodrugs having effective bystander effect and intensive research is needed to tackle these problems and make suicide gene therapy approach really beneficial for patients.

\section{Acknowledgements}

S.J.S F and S.N was supported by Department of Pharmaceuticals, Ministry of Chemical and Fertilizers, Govt. of India, S.N was further supported by Women Scientist Scheme (WOS-A), Department of Science and Technology, Government of India (grant no. SR/WOS-A/ LS-1224/20150) and H.S supported by GPAT, AICTE scholarship.

\section{Conflict of interest}

The authors declare no competing conflict of interest. 


\section{References}

1. Rubanyi GM (2001) The future of human gene therapy. Mol Aspects Med 22: 113-142. [Crossref]

2. Yellepeddi VK (2015) Vectors for non-viral gene delivery-Clinical and Biomedical applications. Austin Ther 2: 1014.

3. Gopinath P, Ghosh SS (2007) Monitoring green fluorescent protein for functional delivery of E. Coli cytosine deaminase suicide gene and the effect of curcumin in vitro. Gene Ther Mol Biol 11: 219-228.

4. Parker K (2001) Vectors of gene therapy In: An introduction to Molecular Medicines and Gene Therapy, Thomas F Kresina Ed John Wiley and Sons Vol. 1: 77-112.

5. Huang Y, Liu X, Dong L, Liu Z, He X, et al. (2011) Development of viral vectors for gene therapy for chronic pain. Pain Res Treat 2011: 968218. [Crossref]

6. Wold WS, Toth K (2013) Adenovirus vectors for gene therapy, vaccination and cancer gene therapy. Curr Gene Ther 13: 421-433. [Crossref]

7. Majhen D, Calderon H, Chandra N, Fajardo CA, Rajan A, et al. (2014) Adenovirusbased vaccines for fighting infectious diseases and cancer: progress in the field. Hum Gene Ther 25: 301-317.

8. Mingozzi F, High KA (2013) Immune responses to AAV vectors: overcoming barriers to successful gene therapy. Blood 122: 23-36. [Crossref]

9. Münch RC, Janicki H, Volker I, Rasbach A, Hallek M, et al. (2013) Displaying highaffinity ligands on adeno-associated viral vectors enables tumor cell-specific and safe gene transfer. Mol Ther 21: 109-118.

10. Lundstrom K (2005) Biology and application of alphaviruses in gene therapy. Gene Ther 12: 92-97. [Crossref]

11. Lundstrom K, Boulikas $\mathrm{T}$ (2003) Viral and non-viral vectors in gene therapy Technology development and clinical trials. Tech in Cancer Res and Treatment 2(: 471-485.

12. Nayerossadat N, Maedeh T, Ali PA (2012) Viral and non-viral delivery systems for gene delivery. Adv Biomed Res 1: 27. [Crossref]

13. Cockrell AS, Kafri T (2007) Gene delivery by lentivirus vectors. Mol Biotechnol 36: 184-204. [Crossref]

14. Parayath NN, Parikh A, Amiji MM (2018) Repolarization of tumor-associated macrophages in a genetically engineered nonsmall cell lung cancer model by intraperitoneal administration of hyaluronic acid-based nanoparticles encapsulating microRNA-125b. Nano Lett 18: 3571-3579.

15. Lee Y, Park EJ, Yu SS, Kim DK, Kim S (2000) Improved expression of vascular endothelial growth factor by naked DNA in mouse skeletal muscles: Implication for gene therapy of ischemic diseases. Biochem Biophys Res Commun 272: 230-235.

16. Ramamoorth M, Narvekar A2 (2015) Non-viral vectors in gene therapy- an overview. $J$ Clin Diagn Res 9: GE01-06. [Crossref]

17. Mehier-Humbert S, Guy RH (2005) Physical methods for gene transfer: improving the kinetics of gene delivery into cells. Adv Drug Deliv Rev 57: 733-753. [Crossref]

18. Wirth T, Ylä-Herttuala S2 (2014) Gene Therapy Used in Cancer Treatment. Biomedicines 2: 149-162. [Crossref]

19. Dorer DE1, Nettelbeck DM (2009) Targeting cancer by transcriptional control in cancer gene therapy and viral oncolysis. Adv Drug Deliv Rev 61: 554-571. [Crossref]

20. Karjoo Z, Ganapathy V, Hatefi A (2013) Gene Directed Enzyme Prodrug Therapy AAPS J 3: 77-91.

21. Kurayoshi K, Ozono E, Iwanaga R, Bradford AP, Komori H, et al. (2014) Cancer cell specific cytotoxic gene expression mediated by ARF tumor suppressor promoter constructs. Biochem Biophys Res Commun 450: 240-246.

22. Kia A, Przystal JM, Nianiaris N, Mazarakis ND, Mintz PJ, et al. (2012) Dual systemic tumor targeting with ligand-directed phage and Grp78 promoter induces tumor regression. Mol Cancer Ther 11: 2566-2577.

23. Zhu ZB, Makhija SK, Lu B, Wang M, Kaliberova L, et al. (2004) Transcriptiona targeting of adenoviral vector through the CXCR4 tumor-specific promoter. Gene Ther 11: $645-648$.

24. Rajendran S, O'Sullivan GC, O'Hanlon D, Tangney M (2013) Adenovirus-mediated transcriptional targeting of colorectal cancer and effects on treatment-resistant hypoxic cells. Clin Colorectal Cancer12: 152-162.
25. Chen XG, Godbey WT (2015) The potential of the human osteopontin promoter and single-nucleotide polymorphisms for targeted cancer gene therapy. Curr Gene Ther 15: 82-92.

26. Nemunaitis J, Tong AW, Nemunaitis M, Senzer N, Phadke AP, et al. (2010) A phase I study of telomerase-specific replication competent oncolytic adenovirus (telomelysin) for various solid tumors. Mol Ther 18: 429-434.

27. Kanegae Y, Terashima M, Kondo S, Fukuda H, Maekawa A, et al. (2011) High leve expression by tissue/cancer-specific promoter with strict specificity using a singleadenoviral vector. Nucleic Acids Res 39: e7.

28. Chuah MK, Petrus I, De Bleser P, Le Guiner C, Gernoux G, et al. (2014) Liver-specific transcriptional modules identified by genome-wide in silico analysis enable efficient gene therapy in mice and non-human primates. Mol Ther 22: 1605-1613.

29. Huber BE, Austin EA, Richards CA, Davis ST, Good SS (1994) Metabolism of 5-fluorocytosine to 5-fluorouracil in human colorectal tumor cells transduced with the cytosine deaminase gene significant antitumor effects when only a small percentage of tumor cells express cytosine deaminase. Proc Natl Acad Sci USA 91: 8302-8306.

30. Bao Q, Zhao Y, Niess H, Conrad C, Schwarz B, et al. (2012) Mesenchymal stem cellbased tumor-targeted gene therapy in gastrointestinal cancer. Stem Cells Dev 21: 2355 2363.

31. Freeman SM, Abboud CN, Whartenby KA, Packman CH, Koeplin DS, et al. (1993) The bystander effect tumor regression when a fraction of the tumor mass is genetically modified. Cancer Res 53: 5274-5283.

32. Malekshah OM, Chen X, Nomani A, Sarkar S, Hatefi A (2016) Enzyme/Prodrug Systems for Cancer Gene Therapy. Curr Pharmacol Rep 2: 299-308. [Crossref]

33. Yoon KJ, Potter PM, Danks MK (2005) Development of prodrugs for enzyme-mediated tumor-selective therapy. Curr Med Chem Anticancer Agents 5: 107-113.

34. Niculescu-Duvaz D, Niculescu-Duvaz I, Springer CJ (2004) Design of prodrugs for suicide gene therapy. Methods Mol Med 90: 161-202. [Crossref]

35. Chen H, Beardsley GP, Coen DM (2014) Mechanism of ganciclovir induced chain termination revealed by resistant viral polymerase mutants with reduced exonuclease activity. Proceed Natl Acad Sci USA 111: 17462-17467.

36. Dong JY, Woraratanadharm J (2005) Gene therapy vector design strategies for the treatment of cancer. Future Oncol 1: 361-373. [Crossref]

37. Wu L, Zhou WB, Shen F, Liu W, Wu HW, et al. (2016) Connexin32 mediate antitumor effects of suicide gene therapy against hepatocellular carcinoma in vitro and in vivo anticancer activity. Mol Med Rep 13: 3213-3219.

38. Adachi M, Sampath J, Lan LB, Sun D, Hargrove P, et al. (2002) Expression of MRP4 confers resistance to ganciclovir and compromises bystander cell killing. J Biol Chem 277: 38998-39004. [Crossref]

39. Chiocca EA, Aguilar LK, Bell SD, Kaur B, Hardcastle J, et al. (2011) Phase IB study of gene-mediated cytotoxic immunotherapy adjuvant to up-front surgery and intensive timing radiation for malignant glioma. J Clin Oncol 29: 3611-3619. [Crossref]

40. Duarte S, Carle G, Faneca H, de Lima MC, Pierrefite-Carle V (2012) Suicide gene therapy in cancer: where do we stand now? Cancer Lett 324: 160-170. [Crossref]

41. Fischer U, Steffens S, Frank S, Rainov NG, Schulze-Osthoff K, et al. (2005) Mechanisms of thymidine kinase/ganciclovir and cytosine deaminase/5-fluorocytosine suicide gene therapy induced cell death in glioma cells. Oncogene 24: 1231-1243.

42. Ostertag D, Amundson KK, Lopez Espinoza F, Martin B, Buckley T, et al. (2012) Brain tumor eradication and prolonged survival from intratumoral conversion of 5 -fluorocytosine to 5-fluorouracil using a nonlytic retroviral replicating vector. J Neurol Oncol 14: 145-159.

43. Kaliberov SA, Buchsbaum DJ (2012) Cancer treatment with gene therapy and radiation therapy. Adv Cancer Res 115: 221-263. [Crossref]

44. Deng LY, Wang JP, Gui ZF Shen LZ (2011) Antitumor activity of mutant bacterial cytosine deaminase gene for colon cancer. World J Gastroenterol 17: 2958-2964.

45. Kaliberov SA, Market JM, Gillespie GY, Krendelchtchikova V, Della Manna D, et al. (2007) Mutation of Escherichia coli cytosine deaminase significantly enhances molecular chemotherapy of human glioma. Gene Ther 14: 1111-1119.

46. Kaliberova LN, Della Manna DL, Krendelchtchikova V, Black ME, Buchsbaum DJ, et al. (2008) Molecular chemotherapy of pancreatic cancer using novel mutant bacterial cytosine deaminase gene. Mol Cancer Ther 7: 2845-2854

47. Wang F, Zamora G, Sun CH, Trinidad A, Chun C, et al. (2014) Increased sensitivity of glioma cells to 5-fluorocytosine following photo-chemical internalization enhanced nonviral transfection of the cytosine deaminase suicide gene. J Neurol Oncol 118: 29-37. 
48. Williams EM, Little RF, Mowday AM, Rich MH, Chan-Hyams JVE, et al. (2015) Nitroreductase gene-directed enzyme prodrug therapy: insights and advances toward clinical utility. Biochem J 471: 131-153.

49. Sharma K, Sengupta K, Chakrapani H (2013) Nitroreductase-activated nitric oxide (NO) prodrugs. Bioorg Med Chem Lett 23: 5964-5967. [Crossref]

50. Vass SO, Jarrom D, Wilson WR, Hyde EI, Searle PF (2009) E. coli NfsA: an alternative nitroreductase for prodrug activation gene therapy in combination with CB1954. $\mathrm{Br} \mathrm{J}$ Cancer 100: 1903-1911. [Crossref]

51. Green LK, Storey MA, Williams EM, Patterson AV, Smaill JB, et al. (2013) The flavin reductase MsuE is a novel nitroreductase that can efficiently activate two promising next-generation prodrugs for gene-directed enzyme prodrug therapy. Cancers (Basel) 5: 985-997.

52. Prosser GA, Copp JN, Syddall SP, Williams EM, Smaill JB, et al. (2010) Discovery and evaluation of Escherichia coli nitroreductases that activate the anti-cancer prodrug CB1954. Biochem Pharmacol 79: 678-687. [Crossref]

53. Prosser GA, Copp JN, Mowday AM, Guise CP, Syddall SP, et al. (2013) Creation and screening of a multi-family bacterial oxidoreductase library to discover novel nitroreductases that efficiently activate the bioreductive prodrugs CB1954 and PR-104 A. Biochem Pharmacol 85: 1091-1103.

54. Patel P, Young JG, Mautner V, Ashdown D, Bonney S, et al. (2009) A phase I/II clinical trial in localized prostate cancer of an adenovirus expressing nitroreductase with CB1984. Mol Ther 17: 1292-1299.

55. Barar J, Omidi Y (2012) Translational approaches towards cancer gene therapy: hurdles and hopes. Biogeosciences 2: 127-143.

56. Hedley D1, Ogilvie L, Springer C (2007) Carboxypeptidase-G2-based gene-directed enzyme-prodrug therapy: a new weapon in the GDEPT armoury. Nat Rev Cancer 7: 870-879. [Crossref]

57. Stribbling SM, Friedlos F, Martin J, Davies L, Spooner RA, et al. (2000) Regressions of established breast carcinoma xenografts by carboxypeptidase G2 suicide gene therapy and the prodrug CMDA are due to a bystander effect. Hum Gene Ther 11: 285-292.

58. Lengler J, Omann M, Duvier D, Holzmuller H, Gregor W, et al. (2006) Cytochrome P450 reductase dependent inhibition of cytochrome P450 2B1 activity implications for gene directed enzyme prodrug therapy. Biochem Pharmacol 72: 893-901.

59. Chiocca EA, Waxman DJ (2004) Cytochrome p450-based gene therapies for cancer. Methods Mol Med 90: 203-222. [Crossref]

60. Gadi VK, Alexander SD, Waud WR, Allan PW, Parker WB, et al. (2003) A longacting suicide gene toxin 6-methylpurine inhibits slow growing tumors after a single administration. J Pharmacol Exp Ther 304: 1280-1284.

61. Parker WB, Allan PW, Waud WR, Hong JS, Sorscher EJ (2011) Effect of expression of adenine phosphoribosyltransferase on the in vivo anti-tumor activity of prodrugs activated by E. coli purine nucleoside phosphorylase. Cancer Gene Ther 18: 390-398.

62. Greco O, Dachs GU (2001) Gene directed enzyme prodrug therapy of cancer historical appraisal and future prospectives. J Cell Physiol 187: 22-36.
63. Francis RJ, Sharma SK, Springer C, Green AJ, Hope-Stone LD, et al. (2002) A phase I trial of antibody directed enzyme prodrug therapy (ADEPT) in patients with advanced colorectal carcinoma or other CEA producing tumours. Br J Cancer 87: 600-607. [Crossref]

64. Spooner R, Friedlos F, Maycroft K, Stribbling S, Roussel J, et al. (2003) A nove vascular endothelial growth factor directed therapy that selectively activates cytotoxic prodrugs. Br J Cancer 88: 1622-1630.

65. Martin J, Stribbling SM, Poon GK, Begent RH, Napier M, et al. (1997) Antibodydirected enzyme prodrug therapy pharmacokinetics and plasma levels of prodrug and drug in a phase I clinical trial. Cancer Chemother Pharmacol 40: 189-201.

66. Ortiz de Montellano PR1 (2013) Cytochrome P450-activated prodrugs. Future Med Chem 5: 213-228. [Crossref]

67. Roy P, Waxman DJ (2006) Activation of oxazaphosphorines by cytochrome P450: application to gene-directed enzyme prodrug therapy for cancer. Toxicol In Vitro 20: 176-186. [Crossref]

68. Kan O, Griffiths L, Baban D, Iqball S, Uden M, et al. (2001) Direct retroviral delivery of human cytochrome P450 2B6 for gene-directed enzyme prodrug therapy of cancer. Cancer Gene Ther 8: 473-482.

69. Chen CS, Jounaidi Y, Waxman DJ (2005) Enantioselective metabolism and cytotoxicity of R-ifosfamide and S-ifosfamide by tumor cell expressed cytochromes P450. Drug Metab Dispos 33: 1261-1267.

70. Ross AD, Varghese G, Oporto B, Carmichael FJ, Israel Y (1995) Effect of propylthiouracil treatment on NADPH-cytochrome P450 reductase levels, oxygen consumption and hydroxyl radical formation in liver microsomes from rats fed ethanol or acetone chronically. Biochem Pharmacol 49: 979-989. [Crossref]

71. Salmons B, Lohr M, Gunzburg WH (2003) Treatment of inoperable pancreatic carcinoma using a cell-based local chemotherapy: results of a phase I/II clinical trial. $J$ Gastroenterol 38: 78-84.

72. Braybrooke JP, Slade A, Deplanque G, Harrop R, Madhusudan S, et al. (2005) Phase I study of MetXia-P450 gene therapy and oral cyclophosphamide for patients with advanced breast cancer or melanoma. Clin Cancer Res 11: 1512-1520.

73. Touati W, Tran T, Seguin J, Diry M, Flinois JP, et al. (2014) A suicide gene therapy combining the improvement of cyclophosphamide tumor cytotoxicity and the development of an anti-tumor immune response. Curr Gene Ther 14: 236-246.

74. Hong JS, Waud WR, Levasseur DN, Townes TM, Wen H, et al. (2004) Excellent in vivo bystander activity of fludarabine phosphate against human glioma xenografts that express the Escherichia coli purine nucleoside phosphorylase gene. Cancer Res 64: 6610-6615.

75. Afshar S, Asai T, Morrison SL (2009) Humanized ADEPT comprised of an engineered human purine nucleoside phosphorylase and a tumor targeting peptide for treatment of cancer. Mol Cancer Ther 8: 185-193.

76. Voeks D, Martiniello-Wilks R, Madden V, Smith K, Bennetts E, et al. (2002) Gene therapy for prostate cancer delivered by ovine adenovirus and mediated by purine nucleoside phosphorylase and fludarabine in mouse models. Gene Ther 9: 759-768.

Copyright: (92019 Panghal A. This is an open-access article distributed under the terms of the Creative Commons Attribution License, which permits unrestricted use, distribution, and reproduction in any medium, provided the original author and source are credited. 